Eur. J. Clin. Chem. Clin. Biochem.

Vol. 32, 1994, pp. $881-884$

(c) 1994 Walter de Gruyter \& Co.

Berlin - New York

\title{
Activity of Class I and II Alcohol Dehydrogenase in the Sera of Alcoholics
}

\author{
By L. Chrostek ${ }^{1}$, M. Szmitkowski ${ }^{1}$ and J. Wierzchowski ${ }^{2}$ \\ 1 Department of Biochemical Diagnostics, Medical School, Bialystok, Poland \\ 2 Department of Physical Chemistry, Medical School, Warsaw, Poland
}

(Received August 15, 1994)

Summary: The activity of class I and II alcohol dehydrogenases in the sera of alcoholics was estimated using specific and highly sensitive fluorogenic substrates. It was found that serum class I activity was increased about 2 fold above that of the control group. No such increase was observed in the activity of class II, and we did not find a significant difference in non-alcoholics. The total alcohol dehydrogenase activity measured by classical spectrophotometric methods at $\mathrm{pH} 9.2$ confirmed the increase of class I alcohol dehydrogenase. Additionally, the activity of liver injury markers were detected. Only $\gamma$-glutamyltransferase activity exceeded the normal range. Based on the results of the present study, we would suggest that the significant elevated serum activity of class I alcohol dehydrogenase may be derived not from liver cells, because they did not display the obvious enzymatic markers, but from different organs, especially the gastrointestinal tract. The tissue distribution of alcohol dehydrogenase isoenzymes and $\gamma$-glutamyltransferase would help to confirm this possibility.

\section{Introduction}

Human alcohol dehydrogenase (EC 1.1.1.1) is a highly polymorphic enzyme ${ }^{1}$ ). The isoenzymes are dimeric and are divided into three classes (I, II, III) on the basis of differences in substrate specificity, sensitivity to inhibitors, immunological properties, and electrophoretic migration (1). Class I of alcohol dehydrogenase isoenzymes are mainly expressed in liver and they are also present in the gastrointestinal tract, kidneys, and lungs $(2,3,4)$. Class II alcohol dehydrogenase is observed only in the liver (5). Class III is present in all examined tissues (6).

Human alcohol dehydrogenase is the main enzymatic system responsible for ethanol oxidation. Class I and II have low $K_{\mathrm{m}}$ ranges, and can effectively metabolize eth-

\footnotetext{
1) Enzymes:

Alcohol dehydrogenase (EC 1.1.1.1)

Alanine aminotransferase (EC 2.6.1.2)

Aspartate aminotransferase (EC 2.6.1.1)

Alkaline phosphatase (EC 3.1.3.2)

$\gamma$-Glutamyltransferase (EC 2.3.2.2)

Lactate dehydrogenase (EC 1.1.1.27)
}

anol in vivo, while class III does not oxidize ethanol up to $2 \mathrm{~mol} / \mathrm{l}$ (7). Alcohol dehydrogenase can metabolize a variety of aliphatic and aromatic alcohols to corresponding aldehydes. This reaction is reversible and the reduction of aldehydes occurs more rapidly than alcohol oxidation (8). Recently, two new aromatic aldehydes similar to the substrates of human alcohol dehydrogenase have been described (9). 4-Methoxy-1-naphthaldehyde is a completely specific and highly sensitive substrate for class I, and 6-methoxy-2-naphthaldehyde for class II enzyme. The products of reduction, 4-methoxy-1-naphthalenemethanol and 6-methoxy-2-naphthalenemethanol, exhibit a strong fluorescence, which can be detected with a spectrofluorimeter. Up to now, only the total activity of alcohol dehydrogenase in serum was detectable, but using this method isoenzymes can be measured even in the subnanomolar range.

The polymorphism of human alcohol dehydrogenase can contribute to the explanation of the important differences in alcohol metabolism between alcoholics and non-alcoholic patients. However, differences in the distribution of hepatic isoenzymes encoded at loci $\mathrm{ADH}_{2}$ 
and $\mathrm{ADH}_{3}$ were not found $(10,11)$. On the other hand, the isoenzyme profile of hepatic alcohol dehydrogenase was altered in alcoholics as compared to non-alcoholics (12). In alcoholics, the hepatic activity of alcohol dehydrogenase changed proportionally with the severity of liver disease $(11,13,14)$ and differences in serum enzyme activity were noted $(14,15)$.

In the present study, we investigated by means of a new fluorimetric method the activity of class I and II isoenzymes of alcohol dehydrogenase in the sera of alcoholics and total alcohol dehydrogenase activity (spectrophotometric method) at $\mathrm{pH} 9.2$ (16). The results can elucidate whether the elevated serum activity derived only from the liver (class II) or probably from the gastrointestinal tract (partly class I) as well, which plays a significant role in first-pass metabolism of ethanol in humans.

\section{Materials and Methods}

Patients

The study was carried out on the sera of 98 patients (men) aged 30-60 years, hospitalized for alcoholism for 10-20 years. Enzyme activity was also assayed in the sera of 50 healthy men (nonalcoholics) as a control group. These patients were classified according to the data obtained by interview, clinical investigations and determinations of aspartate aminotransferase, alanine aminotransferase, lactate dehydrogenase, $\gamma$-glutamyltransferase and alkaline phosphatase.

\section{Chemicals}

4-Methylpyrazole, 4-methoxy-1-naphthaldehyde and ethyl alcohol were purchased from Aldrich Chemicals Company, Inc. (Milwaukee WI). Nicotinamide adenine dinucleotide $\left(\mathrm{NAD}^{+}\right)$and nicotinamide adenine dinucleotide, reduced form (NADH) were obtained from Sigma Diagnostics (St. Louis, MO). 4-Methoxy-1-naphthalenemethanol, 6-methoxy-2-naphthaldehyde and 6-methoxy-2naphthalenemethanol were synthesized by Dr. Jacek Wierzchowski (Department of Physical Chemistry, Medical School, Warsaw, Poland) (9). The diagnostic kits for alanine aminotransferase, aspartate aminotransferase, alkaline phosphatase, $\gamma$-glutamyltransferase and lactate dehydrogenase were obtained from bioMerieux.

\section{Alcohol dehydrogenase assays}

\section{Fluorimetric procedures}

All reaction mixtures $(3 \mathrm{ml})$ were prepared by addition of $150 \mu \mathrm{l}$ of a $300 \mu \mathrm{mol} / 1$ solution of 4-methoxy-1-naphthaldehyde (substrate for class I isoenzymes) or 6-methoxy-2-naphthaldehyde (substrate for class II), $100 \mu \mathrm{l}$ of $1 \mathrm{mmol} / \mathrm{l} \mathrm{NADH}$, and $2.69 \mathrm{ml}$ of $0.1 \mathrm{~mol} / \mathrm{l}$ sodium phosphate buffer, $\mathrm{pH}$ 7.6. After equilibration for $5 \mathrm{~min}$, the reaction was started by the addition of $60 \mu \mathrm{l}$ of serum. Changes in fluorescence were recorded for up to $10 \mathrm{~min}$ on an Aminco Bowman spectrofluorimeter (excitation wavelength $316 \mathrm{~nm}$, emission wavelength $370 \mathrm{~nm}$ for class I and $360 \mathrm{~nm}$ for class II). Sixty $\mu \mathrm{l}$ of product $(200 \mu \mathrm{mol} / \mathrm{l})$ was then added to provide an internal standard and its fluorescence intensity was measured. For the evaluation of alcohol dehydrogenase activity, two assays were carried out: one with substrate and the second with a substrate of $50 \mu 1$ of 12 $\mathrm{mmol} / \mathrm{l}$ solution of 4-methylpyrazole. The rate of reaction (initial velocities) was calculated according to the formula:

$$
\begin{array}{ll} 
& \mathrm{v}=\frac{\mathrm{C}_{\mathrm{st}}}{\mathrm{F}_{\mathrm{st}}} \times \frac{\mathrm{F}_{\mathrm{t}}-\mathrm{F}_{\mathrm{o}}}{\mathrm{t}}[\mu \mathrm{mol} / \mathrm{min}] \\
\mathrm{t} & =10 \text { minutes } \\
\mathrm{F}_{\mathrm{t}}=\text { fluorescence at time } \mathrm{t} \\
\mathrm{F}_{\mathrm{o}}=\text { fluorescence at the beginning of the reaction } \\
\mathrm{C}_{\mathrm{st}}=\text { concentration of the product used as a standard } \\
\mathrm{F}_{\mathrm{st}}=\text { the fluorescence of the added product }
\end{array}
$$

Alcohol dehydrogenase activity concentration was expressed as $\mu \mathrm{mol} / \mathrm{min}$.

\section{Spectrophotometric assays}

Total serum alcohol dehydrogenase activity was estimated at $\mathrm{pH}$ 9.2, which was assumed to give the highest activity for the serum enzyme (16) according to the method of Bonnichsen \& Brink (17) using a Technicon RA-1000 analyzer. The enzyme was assayed at $340 \mathrm{~nm}, 37^{\circ} \mathrm{C}$ for $3 \mathrm{~min}$ in the reaction mixture which contained $18 \mu \mathrm{l}$ of serum, $28 \mathrm{mmol} / \mathrm{l}$ of ethanol, $0.44 \mathrm{mmol} / \mathrm{l} \mathrm{NAD}$ and 344 $\mu \mathrm{l}$ of the buffer $(0.1 \mathrm{mmol} / \mathrm{l}$ glycine buffer $\mathrm{pH} 9.2)$. The control tube contained the reaction mixture without alcohol. Using 12 $\mathrm{mmol} / \mathrm{l}$ of 4-methylpyrazole, artifactual activity was also monitored and subtracted.

\section{Determination of other enzyme activities}

Alanine aminotransferase, aspartate aminotransferase, lactate dehy=drogenase, $\gamma$-glutamyltransferase and lactate dehydrogenase, the liver injury markers, were detected in a Technicon RA-1000 biochemical analyzer using diagnostic kits from bioMerieux.

\section{Statistical analysis}

Statistical analysis was performed using Wilcoxon's test for two independent samples. Differences were considered significant at $\mathrm{p}<0.05$.

\section{Results}

Figure 1 shows the alcohol dehydrogenase activity in the sera of alcoholic and non-alcoholic men.

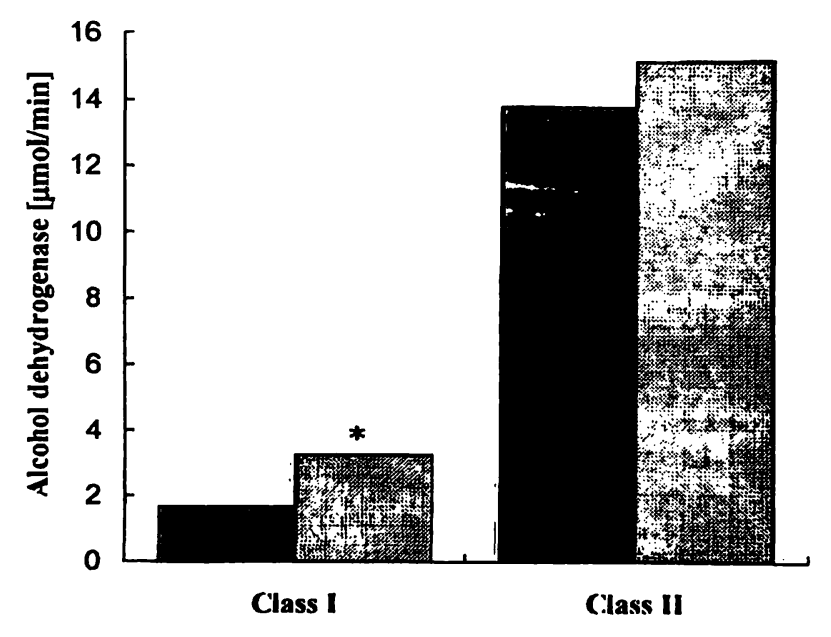

Alcohol dehydrogenase

Fig. 1 The activities of class I and II alcohol dehydrogenase measured by fluorimetric methods in the sera of alcoholics.

The asterisk denotes the significant difference between control group and alcoholics $(p<0.05)$.

controls

alcoholics 
Tab. 1 The activity of total serum alcohol dehydrogenase and enzymatic liver injury markers.

\begin{tabular}{lllllll}
\hline & $\begin{array}{l}\text { Total alcohol } \\
\text { dehydrogenase } \\
\mathrm{U} / \mathrm{l}\end{array}$ & $\begin{array}{l}\text { Aspartate } \\
\text { aminotransferase } \\
\mathrm{U} / 1\end{array}$ & $\begin{array}{l}\text { Alanine } \\
\text { aminotransferase } \\
\mathrm{U} / 1\end{array}$ & $\begin{array}{l}\text { Lactate } \\
\text { dehydrogenase } \\
\mathrm{U} / 1\end{array}$ & $\begin{array}{l}\gamma \text {-Gluatamyl- } \\
\text { transferase } \\
\mathrm{U} / 1\end{array}$ & $\begin{array}{l}\text { Alkaline } \\
\text { phosphatase } \\
\mathrm{U} / 1\end{array}$ \\
\hline Controls & $4.77 \pm 2.05$ & $16.6 \pm 4.8$ & $17.4 \pm 7.5$ & $171.6 \pm 33.7$ & $14.6 \pm 0.5$ & $21.9 \pm 6.8$ \\
Alcoholics & $8.14^{*} \pm 2.78$ & $44.4^{*} \pm 36.0$ & $51.5^{*} \pm 45.4$ & $186.7^{*} \pm 41.4$ & $89.4^{*} \pm 136.3$ & $34.6^{*} \pm 11.6$ \\
\hline
\end{tabular}

The activity of serum class I alcohol dehydrogenase in alcoholics was significantly higher than in non-alcoholics. The activity of class I alcohol dehydrogenase isoenzymes in alcoholics was about 2 times higher than that of the control group and reached a mean value of 3.27 $\mu \mathrm{mol} / \mathrm{min}$. In contrast, the serum activity of class Il alcohol dehydrogenase does not significantly differ between alcoholics and non-alcoholics. Although the analysis indicated a non-significant difference between the mean values of both groups, some alcoholics show a much higher enzyme activity than the mean value of the controls.

Biochemical data of the studied subjects are shown in table 1. A higher activity of liver injury markers were found in the sera of alcoholics than in non-alcoholics. The analysis indicated significant differences between these groups, but only $\gamma$-glutamyltransferase activity exceeds the normal range (up to $75 \mathrm{U} / \mathrm{l}$ ). The activities of other enzymes were elevated but within the ranges found in healthy people (aspartate aminotransferase and alanine aminotransferase up to $50 \mathrm{U} / \mathrm{l}$, lactate dehydrogenase up to $230 \mathrm{U} / 1$ and alkaline phosphatase up to $45 \mathrm{U} / \mathrm{l})$.

\section{Discussion}

It is known that prolonged ethanol abuse is an important factor in hepatic dysfunction (18). We observed that the serum activity of class I alcohol dehydrogenase was significantly higher in alcoholic patients than in controls. In contrast, serum activity of class II alcohol dehydrogenase isoenzymes was similar to controls. Based on these results, we would suggest that the elevated serum activity of class I may be derived from tissues other than the liver. The activity of class I alcohol dehydrogenase isoenzymes is detected especially in stomach and intestinal tissue. It has been well established that human gastric mucosa contains only class I alcohol dehydrogenase isoenzymes in addition to the ubiquitous class III enzyme (7) and that prolonged ethanol intake causes in- flammation of gastric and duodenum mucosa (19). Also, the predominant form of class I alcohol dehydrogenase present in human gastric mucosa is the $\gamma$ subunit (20). In contrast, isoenzymes containing $\beta$ subunits are present in small amounts. This is consistent with our results, as we used 4-methoxy-1-naphthaldehyde which is a good substrate for all isoenzymes of this class with the exception of form $\beta \beta$, which kinetically differs distinctly from other class I isoenzymes (9).

The second possible interpretation of these results may be selective extraction the class I alcohol dehydrogenase isoenzymes from liver cells, in which these isoenzymes are also found. Coman \& Gheorghe (12) reported that liver alcohol dehydrogenase isoenzyme patterns in alcoholic cirrhosis were related to the degree of liver damage. The activity of first anodic isoenzymes and one catodic form, named $A_{1}$ and $C$, respectively, decreased markedly while the activity of the second anodic form $\mathrm{A}_{2}$ was significantly decreased in fatty liver or absent in cirrhosis. The class I alcohol dehydrogenase molecular forms exhibit cathodic mobility in starch gel electrophoresis, whereas class II alcohol dehydrogenase isoenzyme migrates anodically.

We found that the significantly eleyated activity of class I serum alcohol dehydrogenase and the unchanged activity of class II are connected with the results (above normal range) of other biochemical tests of liver damage (except $\gamma$-glutamyltransferase), indicating mild and reversible liver cell damage.

It should also be noted that $\gamma$-glutamyltransferase is present in cell membranes of many tissues.

The activity of class II, similar to the activity of other enzymes of liver origin, was found to be at the upper limit of the normal range, suggesting that in the investigated group we did not observe obvious enzymatic evidence of liver damage but rather increased activity of alcohol dehydrogenase isoenzyme $I$, total alcohol dehydrogenase activity and $\gamma$-glutamyltransferase, which may orginate directly from another tissues damaged by alcohol, especially stomach and intestine. 


\section{References}

1. Vallee, B. L. \& Bazzone, T. J. (1983) Isoenzymes of human liver alcohol dehydrogenase. In: Isoenzymes: Curr. Top. Biol. Med. Res. 8 (Ratazzi, M., Scandalios, J. C. \& Whitt, G. S., eds.) pp. 219-244 New York.

2. Smith, M., Hopkinson, D. A. \& Harris, H. (1971) Developmental changes and polymorphism in human alcohol dehydrogenase. Ann. Hum. Genet. 34, 251-271.

3. Harada, S., Agarwal, D. P. \& Goedde, H. W. (1978) Human liver alcohol dehydrogenase isozyme variations. Hum. Genet. 40, 215-220.

4. Goedde, H. W., Agarwal, D. P. \& Harada, S. (1979) Alcohol metabolizing enzymes: Studies of isozymes in human biopsies and cultured fibroblasts. Clin. Genet. 16, 29-33.

5. Pares, X. \& Vallee, B. L. (1981) New human liver alcohol dehydrogenase forms with unique kinetic characteristics. Biochem. Biophys. Res. Comm. 98, 122-130.

6. Adinolfi, A., Adinolfi, M. \& Hopkinson, D. A. (1984) Immunological and biochemical characterization of human alcohol dehydrogenase $\chi-\mathrm{ADH}$ isozyme. Ann. Hum. Genet. 48, 1-10.

7. Bosron, W. F. \& Li, T.-K. (1987) Catalytic properties of human liver alcohol dehydrogenase isoenzymes. Enzyme 37, 19-28.

8. Ehring, T., Bosron, W. F. \& Li, T.-K. (1990) Alcohol and aldehyde dehydrogenase. Alcohol Alcoholism 25, 105-116.

9. Wierzchowski, J., Dafeldecker, W. P., Holmquist, B. \& Vallee, B. L. (1989.) Fluorometric assays for isozymes of human alcohol dehydrogenase. Anal. Biochem. 178, 57-62.

10. Couzigou, P., Fleury, B., Groppi, A., Cassaigne, A., Begueret, J. \& Iron, A. (1990) Genotyping study of alcohol dehydrogenase class I polymorphism in French patients with alcoholic cirrhosis. Alcohol Alcoholism 25, 623-626.

11. Poupon, R. E., Nalpas, B., Coutelle, Ch., Fleury, B., Couzigou, P., Higueret, D. \& the French Group of Research on Alcohol and Liver (1992) Polymorphism of alcohol dehydrogenase, alcohol and aldehyde dehydrogenase activities: Implication in alcoholic cirrhosis in white patients. Hepatology 15, 10171022.
12. Coman, M. \& Gheorghe, N. (1981) Effects of chronic alcohol intake on isozyme patterns of liver alcohol dehydrogenase. Rev. Roumaine Physiol. 18, 247-249.

13. Panes, J., Soler, X., Pares, A., Caballeria, J., Farres, J., Rodes, J. \& Pares, X. (1989) Influence of liver disease on hepatic alcohol and aldehyde dehydrogeriáses. Gastroenterology 97, $708-714$.

14. Buris, L. \& Varga, M. (1992) Change of alcohol dehydrogenase activity in sera after alcoholism treatment. Eur. J. Clin. Chem. Clin. Biochem. 30, 203-204.

15. Szmitkowski, M. \& Chrostek, L. (1989) Alcohol dehydrogenase $(\mathrm{ADH})$ activity at the different $\mathrm{pH}$ in the sera of alcoholics. In: Biologie Prospective (Galteau, M.-M., ed.) pp. 659662, John Libbey Eurotext.

16. Elghaffar, A. A., Chrostek, L. \& Szmitkowski, M. (1990) Measurement of serum alcohol dehydrogenase activity at different pH-values during the course of viral hepatitis in children. J. Clin. Chem. Clin. Biochem. 28, 497-499.

17. Bonnichsen, R. K. \& Brink, N. O. (1955) Liver alcohol dehydrogenase. In: Methods in Enzymology, Vol. 1 (Colowick, S. P. \& Nathan, N. O., eds.) pp. 495-500, Acảdemic Press, New York.

18. Lieber, C. S. (1990) Mechanism of ethanol induced hepatic injury. Pharmac. Ther. 46, 1-41.

19. Lieber, C. S. (1984) Alcohol and the liver: Metabolism of ethanol, metabolic effects and pathogenesis of injury. Acta Med. Scand. 703, 11-55.

20. Shmith, M., Hopkinson, D. A. \& Harris, H. (1973) Studies on the properties of the human alcohol dehydrogenase isozymes determined by the different loci ADH1, ADH2, ADH3. Ann. Hum. Genet. 37, 49-67.

M. Szmitkowski M.D., Ph.D. Department of Biochemical Diagnostics Institute of Laboratory Diagnostics Medical School

M. Skłodowska-Curie 24A

PL 15-276 Białystok

Poland 